\title{
The Effect of Teacher Efficacy of Early Childhood Teachers on Teacher Happiness
}

\author{
Soon-ok Joo ${ }^{1}$ and Sung-je $\mathrm{Cho}^{2 *}$ \\ ${ }^{1}$ (Ph.D. course/doctorate course) 02838 Department of Regional and Welfare \\ Administration Department, Dongbang Culture Graduate Univ., 28 Sungbok-Ro, \\ Sungbokdong, Seoul, Korea \\ ${ }^{2 *} 02838$ Department of Regional and Welfare Administration Department, Dongbang \\ Culture Graduate Univ., 28 Sungbok-Ro, Sungbokdong, Seoul, Korea \\ ljesus9106@naver.com, ${ }^{2 *}$ chosj715@daum.net
}

\begin{abstract}
The purpose of this study is to understand the effect of teacher efficacy of early childhood teachers on teacher happiness. The study was conducted on 153 early childhood teachers of Ulsan Metropolitan City. Frequency analysis, reliability analysis, and correlation analysis were performed using the SPSS 22.0 program. Multiple regression analysis was performed on causality between variables. The results of this study are as follows: First, teachers' efficacy factors of early childhood teachers showed that both general teacher efficacy and personal teacher efficacy had a significant effect on teacher's internal happiness. Second, teachers' efficacy factors of early childhood teachers showed that both general teacher efficacy and personal teacher efficacy had a significant effect on teacher's external happiness. Third, teachers' efficacy factors of early childhood teachers showed that both general teacher efficacy and personal teacher efficacy had a significant effect on teacher's self-regulated happiness. This study is expected to be the basic data for the practical intervention plan for the improvement of teacher efficacy and teacher happiness of early childhood teachers.
\end{abstract}

Keywords: Early childhood teachers, General teacher efficacy, Personal teacher efficacy, Teacher happiness, Infants and toddlers

\section{Introduction}

\subsection{The need for research}

With the recent increase in working married couples, infant and child care has been shifted from home to early childhood education institutions. Considering the increase in the amount of time infants are staying in institutions nowadays, adequate child care for infants and toddlers is crucial. Therefore, the presence of early childhood teachers who

Article history:

Received (April 11, 2019), Review Result (May 9, 2019), Accepted (June 4, 2019) 
spend ever-increasing amount of time with infants and toddlers is an important factor affecting the happiness of the children [1]. Especially, the variables of happiness of infants and toddlers have a direct influence on their emotional intelligence, and kindergarten adaptation has been reported to have an indirect influence on emotional intelligence of children [2]. Thus, emotional intelligence plays an important role in children's kindergarten adaptation and happiness. In addition, the emotional intelligence of early childhood teachers was found to affect not only the positive interaction between children and teachers but also the happiness of the children. This suggests that the emotional intelligence of early childhood teachers has positive effects on their relationship with children as well as the happiness of children [3]. Therefore, the influence of the teachers' emotional intelligence on the happiness of children was confirmed.

The positive emotional intelligence of the early childhood teachers was reported to be high in children's as well as their personal happiness [4]. Thus, positive emotional intelligence of early childhood teachers is an important factor for happiness. Moreover, the relative explanatory power of independent variables on the happiness of early childhood teachers was in the order of resilience and teacher efficacy [5].

The results of the analysis of the effect of kindergarten teachers' happiness on egoresilience and teacher efficacy showed that there was a statistically significant correlation between kindergarten teachers' happiness, ego-resilience and teacher efficacy. This implies that the euphoria of kindergarten teachers has an important influence on ego-resilience and teacher efficacy [6].

As a result of analyzing the effect of kindergarten teachers on happiness, it was reported that teacher efficacy and job satisfaction of early childhood teachers had a positive effect on happiness. Therefore, it is necessary to improve teacher efficacy in order to improve the quality of education for infants and toddlers by efficiently performing the tasks of infant and child teachers. The reason for this is that teacher efficacy of early childhood teachers has a positive effect on job satisfaction [7].

The initial research on the teacher efficacy of kindergarten teachers showed that the resilience of early childhood teachers according to the individual variables of early childhood teachers affects teacher efficacy and job exhaustion [8].

The results of the previous studies suggest the necessity of research on the effect of teacher efficacy on teachers' happiness. In previous research, resilience, job exhaustion, and teaching stress of early childhood teachers have been studied. However, not much research has been done on the happiness of early childhood teachers. The purpose of this study is to provide the basic data for the improvement of teacher efficacy and teacher happiness of early childhood teachers by clarifying the effect of teacher efficacy on teachers' happiness.

\subsection{Research objectives}

The purpose of this study is to analyze the effect of teacher efficacy on teacher happiness. The research questions are as follows.

First, what is the effect of teacher efficacy on early childhood teachers' inner happiness? 
Second, what is the effect of teacher efficacy on early childhood teachers' external happiness?

Third, what is the effect of teacher efficacy on early childhood teachers' selfregulated happiness?

\section{Research methods and results}

\subsection{Reliability of major variables}

As a result of the reliability test of each variable used in this study, the reliability of the general teacher efficacy of .846 , personal teacher efficacy of .818 , and total reliability of .833 , which are sub - factors of teacher efficacy, are shown. The reliability of teachers' euphoria was as high as following subordinate factors: internal happiness .916 , external happiness .934 , self-regulated euphoria .946 total reliability .954 .

Table 1. Reliability of major variables

\begin{tabular}{|c|c|c|c|c|}
\hline \multicolumn{2}{|c|}{ Category } & Question Number & \multicolumn{2}{|c|}{ Cronbach's $\alpha$} \\
\hline \multirow{2}{*}{ Teacher Efficacy } & General Teacher Efficacy & 12 & .846 & \multirow{2}{*}{.833} \\
\cline { 2 - 4 } & Personal Teacher Efficacy & 13 & .818 & \\
\hline \multirow{2}{*}{$\begin{array}{c}\text { Teacher } \\
\text { Happiness }\end{array}$} & Internal Happiness & 10 & .916 & \multirow{2}{*}{.954} \\
\cline { 2 - 4 } & External Happiness & 9 & .934 & .946 \\
\cline { 2 - 4 } & Self-regulated Happiness & 9 &. & \\
\hline
\end{tabular}

\subsection{Demographic characteristics}

As a result of examining the demographic and sociological characteristics of childhood teachers, it was found that 153 were all female, and $79(51.6 \%)$ were in the 40s. In terms of marital status, $111(72.5 \%)$ were married and $42(27.5 \%)$ were unmarried. The current position is homeroom teachers $(71.2 \%)$ with the highest rate. In terms of working experience, the number of people who worked more than three years and less than six years was $50(32.7 \%)$, which is the largest number.

Table 2. Demographic characteristics

\begin{tabular}{|c|c|c|c|}
\hline \multirow{2}{*}{\multicolumn{2}{|c|}{ Category }} & \multicolumn{2}{c|}{ Total (N=153) } \\
\cline { 3 - 4 } & Male & Frequency & Percentage (\%) \\
\hline \multirow{3}{*}{ Gender } & Female & 153 & 0.0 \\
\cline { 2 - 4 } & $20 \mathrm{~s}$ & 23 & 100.0 \\
\hline \multirow{3}{*}{ Age } & $30 \mathrm{~s}$ & 41 & 15.0 \\
\cline { 2 - 4 } & $40 \mathrm{~s}$ & 79 & 26.8 \\
\cline { 2 - 4 } & Over 50s & 10 & 51.6 \\
\cline { 2 - 4 } & Single & 42 & 6.5 \\
\hline \multirow{2}{*}{ Marital Status } & Married & 111 & 27.5 \\
\hline Current Position & After-school and Full-time Teachers & 5 & 72.5 \\
\cline { 2 - 4 } & & 3.3 \\
\hline
\end{tabular}




\begin{tabular}{|c|c|c|c|}
\hline \multirow{4}{*}{} & Assistant Teacher & 16 & 10.5 \\
\cline { 2 - 4 } & Homeroom Teacher & 109 & 71.2 \\
\cline { 2 - 4 } & Head Teacher & 11 & 7.2 \\
\cline { 2 - 4 } Work Experience & Vice Principal & 12 & 7.8 \\
\cline { 2 - 4 } & Between 1-3 years & 47 & 30.7 \\
\cline { 2 - 4 } & Between 3-6 years & 50 & 32.7 \\
\cline { 2 - 4 } & Between 6-10 years & 24 & 15.7 \\
\cline { 2 - 4 } & Between 10-15 years & 23 & 15.0 \\
\cline { 2 - 4 } & Over 15 years & 9 & 5.9 \\
\hline
\end{tabular}

\subsection{Technical statistics on key variables}

The results of the descriptive statistics for the main variables of this study were as follows. The variables of the main variables of the childhood teacher were measured by the 5 points scale. Teacher 's self - efficacy was the highest $(\mathrm{M}=3.51)$.

Table 3. Technical statistics on key variables

\begin{tabular}{|c|c|c|c|c|c|c|}
\hline \multicolumn{2}{|c|}{ Category } & $\mathrm{N}$ & $\begin{array}{c}\text { Minimum } \\
\text { Value }\end{array}$ & $\begin{array}{c}\text { Maximum } \\
\text { Value }\end{array}$ & $\mathrm{M}$ & $\mathrm{SD}$ \\
\hline \multirow{2}{*}{$\begin{array}{c}\text { Teacher } \\
\text { Efficacy }\end{array}$} & $\begin{array}{c}\text { General Teacher } \\
\text { Efficacy }\end{array}$ & 153 & 2.48 & 4.35 & 3.36 & .31 \\
\cline { 2 - 7 } & $\begin{array}{c}\text { Personal Teacher } \\
\text { Efficacy }\end{array}$ & 153 & 2.53 & 4.75 & 3.51 & .50 \\
\hline
\end{tabular}

\subsection{Technical statistics on key variables}

For the descriptive statistics on the main variables of this study, the measurement variables of the main variables of the childhood teacher were measured by the 5 points scale and the external happiness $(\mathrm{M}=3.64)$ was found to be the highest.

Table 4. Technical statistics on key variables

\begin{tabular}{|c|c|c|c|c|c|c|}
\hline \multicolumn{2}{|c|}{ Category } & $\mathrm{N}$ & Minimum & Maximum & M & SD \\
\hline \multirow{2}{*}{$\begin{array}{c}\text { Teacher } \\
\text { Happiness }\end{array}$} & Internal Happiness & 135 & 2.00 & 4.80 & 3.62 & .59 \\
\cline { 2 - 7 } & External Happiness & 135 & 2.33 & 4.78 & 3.64 & .54 \\
\cline { 2 - 7 } & $\begin{array}{c}\text { Self-regulated } \\
\text { Happiness }\end{array}$ & 135 & 1.67 & 4.78 & 3.52 & .57 \\
\hline
\end{tabular}

\subsection{Correlation between key variables}

As for the relationship between teacher efficacy and teacher's happiness, Teacher efficacy and personal teacher efficacy $(\mathrm{r}=.361, \mathrm{p}<.01)$ showed a low correlation and teacher efficacy and internal euphoria $(\mathrm{r}=.552, \mathrm{p}<.01)$ showed somewhat low correlation. External happiness and internal happiness $(\mathrm{R}=.900, \mathrm{p}<.01)$, External happiness and self-regulated euphoria $(r=.846, \mathrm{p}<.01)$ were found to be high level of correlation. 
Table 5. Correlation between key variables

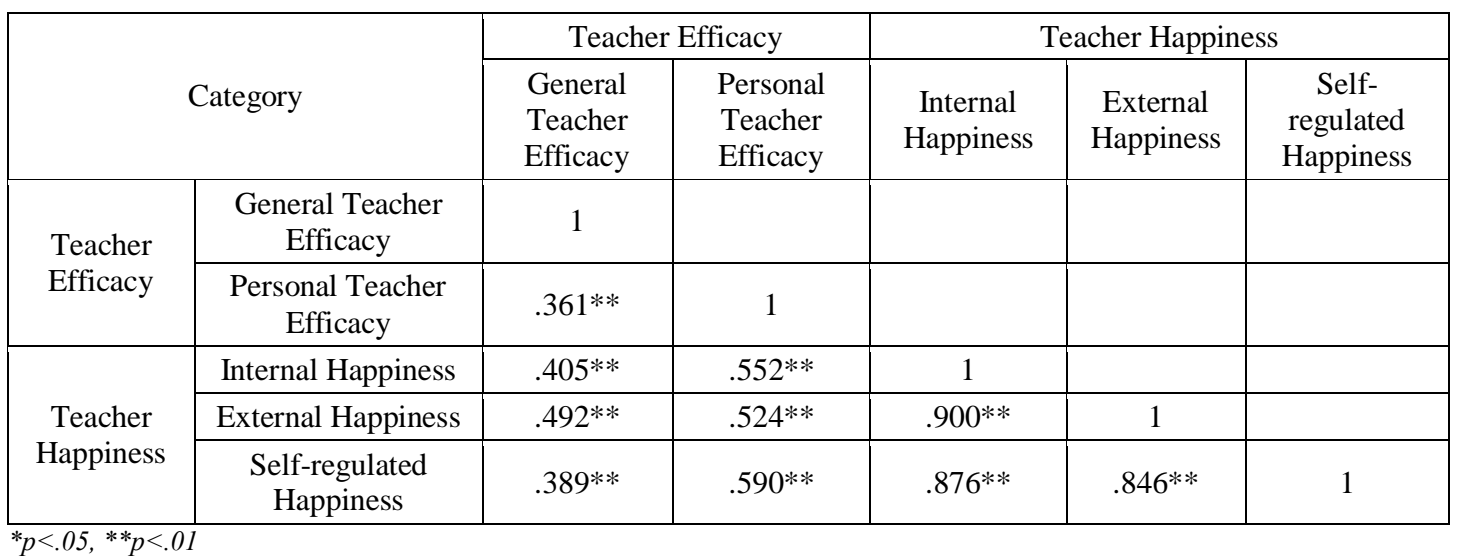

\subsection{The effect of teacher efficacy on external happiness of early childhood teachers}

As a result of examining the effect of teacher efficacy on external happiness, The R2 square value, which represents the explanatory power of the teacher efficacy of childhood teacher of external happiness, is .380 , which accounts for $38.0 \%$ of the total variation. The variance analysis of the model showed that the estimated regression model $(\mathrm{F}=45.986, \mathrm{p}<.000)$ was statistically significant. In terms of the sub-factors of teacher efficacy, Teacher efficacy $(\beta=.398, p<.05)$ and general teacher efficacy $(\beta=.348$, $\mathrm{p}<.05)$ have significant influence on external happiness. This means that the higher the teacher self-efficacy factor and the general teacher efficacy factor are, the higher the external happiness of the childhood teacher.

Table 6. The effect of teacher efficacy on external happiness of early childhood teachers

\begin{tabular}{|c|c|c|c|c|c|c|c|}
\hline \multirow{2}{*}{$\begin{array}{c}\text { Dependent } \\
\text { Variable }\end{array}$} & \multirow{2}{*}{$\begin{array}{c}\text { Independent } \\
\text { Variable }\end{array}$} & \multicolumn{2}{|c|}{$\begin{array}{c}\text { Non-standardization } \\
\text { Factor }\end{array}$} & \multirow{2}{*}{$\begin{array}{c}\text { Standardization } \\
\text { Factor }\end{array}$} & \multirow{2}{*}{$\mathrm{t}$} & \multicolumn{2}{|c|}{ Multicollinearity } \\
\hline & & B & Standard Error & & & $\begin{array}{c}\text { Tolerance } \\
\text { limit }\end{array}$ & VIF \\
\hline \multirow{3}{*}{$\begin{array}{l}\text { External } \\
\text { Happiness }\end{array}$} & Constant & .099 & .393 & & .251 & & \\
\hline & $\begin{array}{l}\text { General } \\
\text { Teacher } \\
\text { Efficacy }\end{array}$ & .602 & .119 & .348 & $5.053 * * *$ & .870 & 1.150 \\
\hline & $\begin{array}{l}\text { Personal } \\
\text { Teacher } \\
\text { Efficacy }\end{array}$ & .432 & .075 & .398 & $5.776 * * *$ & .870 & 1.150 \\
\hline
\end{tabular}

\subsection{Family adaptability and psychological well-being according to marital status}

The effects of childhood teacher efficacy on self-regulated euphoria were as follows. The R2 square value, the explanatory power of the teacher efficacy of self-regulated euphoria, is .383 , which accounts for $38.3 \%$ of the total variance. The variance analysis 
of the model showed that the estimated regression model $(\mathrm{F}=46.561, \mathrm{p}<.000)$ was statistically significant.

When we examine the influence according to sub-factors of teacher efficacy, teacher efficacy $(\beta=-.517, p<.05)$ was found to have a significant influence on self-regulated euphoria. This implies that self-regulated euphoria increases as teacher self-efficacy factor among the sub- factors of teacher efficacy of childhood teachers.

Table 7. Family adaptability and psychological well-being according to marital status

\begin{tabular}{|c|c|c|c|c|c|c|c|}
\hline \multirow{2}{*}{$\begin{array}{l}\text { Dependent } \\
\text { Variable }\end{array}$} & \multirow{2}{*}{$\begin{array}{c}\text { Independent } \\
\text { Variable }\end{array}$} & \multicolumn{2}{|c|}{$\begin{array}{c}\text { Non-standardization } \\
\text { Factor }\end{array}$} & \multirow{2}{*}{$\begin{array}{c}\begin{array}{c}\text { Standardization } \\
\text { Factor }\end{array} \\
\beta\end{array}$} & \multirow{2}{*}{$\mathrm{t}$} & \multicolumn{2}{|c|}{ Multicollinearity } \\
\hline & & B & $\begin{array}{c}\text { Standard } \\
\text { Error }\end{array}$ & & & $\begin{array}{l}\text { Tolerance } \\
\text { limit }\end{array}$ & VIF \\
\hline \multirow{3}{*}{$\begin{array}{c}\text { Self- } \\
\text { regulated } \\
\text { Happiness }\end{array}$} & Constant & .204 & .414 & & .492 & & \\
\hline & $\begin{array}{l}\text { General } \\
\text { Teacher } \\
\text { Efficacy }\end{array}$ & .369 & .126 & .202 & $2.937 * *$ & .870 & 1.150 \\
\hline & $\begin{array}{l}\text { Personal } \\
\text { Teacher } \\
\text { Efficacy }\end{array}$ & .592 & .079 & .517 & $7.511 * * *$ & .870 & 1.150 \\
\hline
\end{tabular}

\section{Conclusion}

In this study, we analyzed the effect of teacher's happiness on the quality of life of early childhood teachers. The following discussion is based on the results of the analysis.

First, among the sub-factors of teacher efficacy perceived by early childhood teachers, general teacher efficacy and personal teacher efficacy factors have significant influence on teacher's internal happiness.

Second, among the sub-factors of teacher efficacy perceived by early childhood teachers, general teacher efficacy and personal teacher efficacy factors have significant influence on teacher's external happiness.

Third, among the sub-factors of teacher efficacy perceived by early childhood teachers, general teacher efficacy and personal teacher efficacy factors have significant influence on teacher's self-regulated happiness.

As discussed above, the need for teacher efficacy is increasing for quality of life in various aspects of early childhood teachers. Therefore, the implication of this study is that the analysis of the effect of teacher efficacy on teacher happiness was found to be significant. Based on the results of this study, it can be seen that teachers' happiness is important for providing quality childcare services to children attending early childhood education institutions. Therefore, to improve quality of life of early childhood teachers, it is necessary to develop an educational program on emotional stability so that teacher efficacy may be enhanced. In order to improve the happiness by promoting the teacher efficacy of the early childhood teachers in the future, concrete study is needed for the practical intervention plan in the education field. 


\section{Acknowledgements}

I am deeply moved by the thought of Professor Sung-je Cho who have guided me, and family while watching my lovely and precious papers. I would also like to express my gratitude to the staff who have helped and the children who always welcome with laughter.

\section{References}

[1] M. R. Kim, E. H. Lee, and Y. J. Lee, "The effect of teachers stress, teacher-child interaction and teachers efficacy on teachers happiness," The Journal of Korea Open Association for Early Childhood Education, vol.23, no.4, pp.57-76, (2018)

[2] H. Go and S. M. Kim, "The relations among children`s emotional intelligence, kindergarten adaptation, and happiness," The Journal of Korea Early Childhood Education, vol.21, no.4, pp.115-136, (2014)

[3] H. J. Jeon, K. N. Lee, and E. K. Goh, "The effects of early childhood teachers' emotional intelligence on young children`s happiness: based on mediating effects of teachers` job satisfaction,” Korean Journal of Child Studies, vol.36, no.6, pp.125-146, (2015)

[4] C. Heesun, "Effects of emotional intelligence and communication competence on the happiness of early childhood teachers: the mediating effects of communication competence," The Journal of Korea Open Association for Early Childhood Education, vol.22, no.1, pp.303-323, (2017)

[5] H. I. Hwang, J. H. Tak, and S. H. Hong, "Impact of resilience, teacher efficacy, and job satisfaction on happiness in early childhood teachers," Early Childhood Education Research \& Review, vol.17, no.3, pp.411432, (2013)

[6] S. R. Kim and I. S. Choi, "The effects of kindergarten teachers' happiness on ego resilience and teacher efficacy, Child care support research," vol.12, no.1, pp.29-51, (2017)

[7] E. -H. Gong, "Meta-analysis of the correlation between early childhood teachers teaching efficacy and their job satisfaction," Journal of The Korea Contents Association, vol.16, no.1, pp.391-402, (2016)

[8] S. K. Woo and K. Kim, "Early childhood teachers resilience, teacher-efficacy, and job-burnout by personal background," Korea Journal of Child Care and Education 95, pp.105-125, (2015)

\section{Authors}

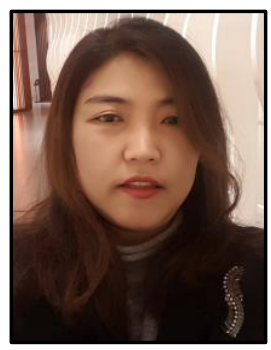

\section{Soon-ok Joo}

2010 present Professor, Daegu Catholic University and Graduate School 
The Effect of Teacher Efficacy of Early Childhood Teachers on Teacher Happiness

This page is empty by intention. 